\title{
Managing the Internationalization Strategy of Private University
}

\author{
Ratih Indraswari
}

\begin{abstract}
Internationalization of higher education has been gaining increasing importance. Transfer of knowledge benefits not only the institution but also the staffs \& students, bringing about positive opportunities to the academic constituents across the traditional state boundaries. Considering the imperative of internationalization strategy as part of higher education performa, the issues of managing the international cooperation amongst universities requires a thorough analysis. This paper tries to see the dynamic efforts of internationalization strategy of private university amidst the given constraint available. An analysis on the correlation to global trend will be given and followed by lesson learned on a unique resource allocation management in order to support the internationalization strategy. A study case on Parahyangan Catholic University as an individual private university will be presented in finding the answer to the questions above.
\end{abstract}

Index Terms - Higher education, internationalization, middle university, mobility.

\section{INTRODUCTION}

As the home of more than 4300 higher education institutions, Indonesia has the potential to develop its education sector to achieve a World Class University status. However the mushrooming of contemporary higher education institution in Indonesia does not entitled to the increase status of Indonesia as the source of knowledge. This phenomenon poses a dilemmatic equation. The increase of higher education institutions in Indonesia is an answer to the demand driven by the population booming. Yet does the increase of quantity equivalent to the increase of quality of knowledge as well? Unfortunately, the answer is not quite. The government is faced by the overwhelming numbers of higher education institutions but only few of that number are actually able to compete internationally independently.

There are more than 4000 private higher educations that make up more than $90 \%$ of Indonesia's education profile, yet some still struggle to be recognized nationally [1]. Private universities flourished to ensure more opportunity are available for students as public universities are not able to fully absorb the spiking number of education seekers. However, their establishment is not free from problem. The surging of private universities adds particular problem to the overall policy of Indonesia's education. Funding becomes an important challenge on management level faces by private universities. This is especially true in which private universities must rely on their own self-funding mechanism

Manuscript received November 21, 2017; revised January 20, 2018.

Ratih Indraswari is with Parahyangan Catholic University Bandung Indonesia (e-mail: ratih.indraswari@unpar.ac.id). to ensure their survival. Funding allocation must be managed wisely to cover not only the day-to-day business of teaching and researching but also funding consequences resulted from regulations set by the national government.

Amidst the background of higher education's national policy on international affairs, it is suggested that Indonesia puts primacy on the adoption on the strategy of nurturing a small group of public universities to be endorsed into the global level. The World Class University status is competitive. The government has made a rational choice to focus its energy and resources on several universities. Even though private universities in Indonesia are eligible to receive stimulus package by the government to endorse their capacity to gain international reputation, this opportunities are limited. As a consequence, private universities must find alternatives ways to be able to take part in the internationalization trend.

\section{INTERNATIONALIZATION OF HIGHER EDUCATION}

Internationalization of higher education is the 'process of integrating an international, intercultural or global dimension into the purpose, functions of delivery of higher education' [2].

The concept of internationalization has been established in parallel to the wake of globalization. It sits on the notion that internationalization is 'creating a sense of global in higher education' [3]. Some view see internationalization as independent of globalization. Globalization according to this perspective is seen solely associated with economic functions; suggesting that internationalization is 'a reaction to phenomenon of globalization' [4]. In other words globalization thus, is different from internationalization.

Globalization is also understood as 'a system and relationship that are practiced beyond the local and national dimension at continental, meta-nation regional and world levels' in which internationalization of higher education is part of the those system and relationship [3]. Although internationalization of higher education is argued as an integral part of globalization, its position in correlation to globalization has yet received a clear delineation. For those focusing on national border as the defining character of globalization, the phenomenon of internationalization positions itself awkwardly to the idea of border. For example student's mobility across national boundaries has exemplified the globalization concept, in which mobilization is no longer confined within a traditional state border. However, the establishment of Universities ranking has constrained the elimination of conventional state boundaries by celebrating the placement of universities within its respective countries of origins. This confusion is shared 
widely, 'it is clear that internationalization means different things to different people and as results there is a great diversity of interpretations attributed to the concept' [4].

Despite the conundrum resulted in defining internationalization concept, research on higher education has acquired an increasing development. The study on higher education received its primary academic support through the establishment of Journal of Studies in International Higher Education. This platform provides a framework for exchanges of researches and knowledge on internalization of higher education institutions,

Particularly there are two recent developments in the internationalization study compare to the 90's era. First, the study has shifted into focusing on publication targeting more practitioner and policy makers, less on researchers. Secondly, the issues expanded integrating other field of studies into the research, most notably studies of management and economic, international relations and politics as well as public policy. These developments are particularly important as it allows different perspectives enriching the overall study. Contribution from practitioners and policy makers adds the element of 'reality' to the academic studies, while the involvement of broader studies allows researchers and practitioners to enjoy wider utilization of available varied perspectives. However, at the same time these developments lend to the confusion of concept due to lack of clarification on conceptual or definitional matter making the research on internationalization of higher education more 'fuzzy' [4].

Few big themes adopted for research on internationalization have been presented by scholars [5]. This theme provides the 'landscape of systemic studies' [4] in which each theme can be translated into several sub-themes.
Additionally, the study holds a higher degree of integration not only with other studies but also among each themes and sub -themes. This provides opportunity for combination study with overlapping content. A similar findings has been forwarded that the practice of internationalization of higher education 'usually refers to one OR combination' of several activities consisting; topic and activities involving the international mobility; movement of students between countries an; mobility of academic staff and researchers [6].

\section{INTERNATIONALIZATION STRATEGY: GLOBAL TREND}

A previous research has been conducted in determining how does internationalization strategy of higher education translated by universities [7]. This finding has showed that priorities of policies can be categorized into several strategies that are formulated in accordance to the goals universities want to achieve. Globally, $44 \%$ of universities translate their internationalization strategy to encourage for an increase of outbound students, this number is followed closely with up to $43 \%$ universities are in return also looking to receive inbound students to their universities. Following closely, $40 \%$ of universities see that international research collaboration is another strategy of internationalization of universities.

The global study is further translated into regional profile in which each region devises its own priorities. Most regions share the vision that outbound students mobility constitutes the majority of internationalization activities.

TABLE I: GLOBAL INTERNASIONALIZATION STRATEGY

\begin{tabular}{|l|l|l|l|l|l|l|l|}
\hline & World & Africa & $\begin{array}{l}\text { Asia- } \\
\text { Pacifik }\end{array}$ & Europa & L. America and Caribia & Middle East & N. America \\
\hline $\begin{array}{l}\text { Outgoing mobility } \\
\text { opportunities for } \\
\text { students } \\
\text { internship etc) }\end{array}$ & $44 \%$ & $29 \%$ & $40 \%$ & $49 \%$ & $45 \%$ & $18 \%$ & $43 \%$ \\
\hline $\begin{array}{l}\text { International student } \\
\text { exchange attracting } \\
\text { international students }\end{array}$ & $43 \%$ & $27 \%$ & $50 \%$ & $45 \%$ & $29 \%$ & $35 \%$ & $42 \%$ \\
\hline $\begin{array}{l}\text { International research } \\
\text { collaboration }\end{array}$ & $40 \%$ & $46 \%$ & $52 \%$ & $41 \%$ & $35 \%$ & $32 \%$ & $23 \%$ \\
\hline $\begin{array}{l}\text { Strengthening } \\
\text { international/intercult } \\
\text { ural content of the } \\
\text { curriculum }\end{array}$ & $31 \%$ & $29 \%$ & $33 \%$ & $30 \%$ & $27 \%$ & $40 \%$ \\
\hline $\begin{array}{l}\text { Joint and dual/double } \\
\text { degree programmes }\end{array}$ & $30 \%$ & $24 \%$ & $27 \%$ & $35 \%$ & $27 \%$ & $30 \%$ \\
\hline
\end{tabular}

European universities mirror the global trend of internationalization strategy. This global pattern is also shared partially by the North American universities. However North American universities see the strengthening of international /intercultural content of curriculum is far more important rather than focusing on international research collaboration.

Latin America \& Caribbean universities too interpret outbound students mobility as their internationalization strategy. However the reciprocity of inbound students to the region occupies a less preference in comparison to international research collaboration.

Middle East universities adopt priorities to receive inbound international students and subsequent policies follows the aim to increase quality of research through international research collaboration as well through dual or joint double degree.

In Africa, international research collaboration occupies the prime strategy of internationalization, followed by the need to increase for outbound students and the strengthening of international/intercultural curriculum.

Lastly, in Asia Pacific, internationalization strategy for 
universities relies heavily on the international research collaboration. Subsequently, they keen to receive more inbound students primarily before seeking to send more outbound students abroad.

TABLE II: GLOBAL INTERNASIONALIZATION AIM

\begin{tabular}{|c|c|c|c|c|c|c|c|}
\hline & World & Africa & $\begin{array}{l}\text { Asia- } \\
\text { Pacifik }\end{array}$ & Europa & $\begin{array}{l}\text { L. America } \\
\text { and Caribia }\end{array}$ & $\begin{array}{l}\text { Middle } \\
\text { East }\end{array}$ & $\begin{array}{l}\text { N. } \\
\text { America }\end{array}$ \\
\hline $\begin{array}{l}\text { Improve student preparedness for a } \\
\text { globalized/internationalized world }\end{array}$ & $30 \%$ & $19 \%$ & $31 \%$ & $27 \%$ & $39 \%$ & $22 \%$ & $39 \%$ \\
\hline $\begin{array}{l}\text { Internationalize curriculum and improve } \\
\text { academic quality }\end{array}$ & $17 \%$ & $15 \%$ & $17 \%$ & $16 \%$ & $18 \%$ & $16 \%$ & $17 \%$ \\
\hline Enhance international profile and reputation & $15 \%$ & $13 \%$ & $14 \%$ & $20 \%$ & $6 \%$ & $17 \%$ & $9 \%$ \\
\hline $\begin{array}{l}\text { Strengthen research and capacity knowledge } \\
\text { production }\end{array}$ & $14 \%$ & $24 \%$ & $15 \%$ & $13 \%$ & $16 \%$ & $22 \%$ & $8 \%$ \\
\hline $\begin{array}{l}\text { Increase the number, broaden and diversify } \\
\text { source of students }\end{array}$ & $9 \%$ & $8 \%$ & $7 \%$ & $10 \%$ & $4 \%$ & $5 \%$ & $17 \%$ \\
\hline
\end{tabular}

\section{NATIONAL OUTLOOK: INDONESIA HIGHER EDUCATION}

Indonesia hosts a massive number of higher education institutions, making Indonesia as the prime home of education institutions in Southeast Asia. This number is divided between private and public higher education institutions, in which each section comprises of several type of higher education institutions. General number has it that private higher education institutions contribute significantly to Indonesia's education sector by adding up to 4084 institutions in comparison to 372 public institutions. More than $90 \%$ of total Indonesian higher education services are provided by private higher education institutions. On the university level, there are 75 public universities and 466 private universities covering the vast amount of the archipelagic. Indonesia's total population is projected to rise to 270 million in 2025 making education therefore an important element to ensure the development of the nation. [1].

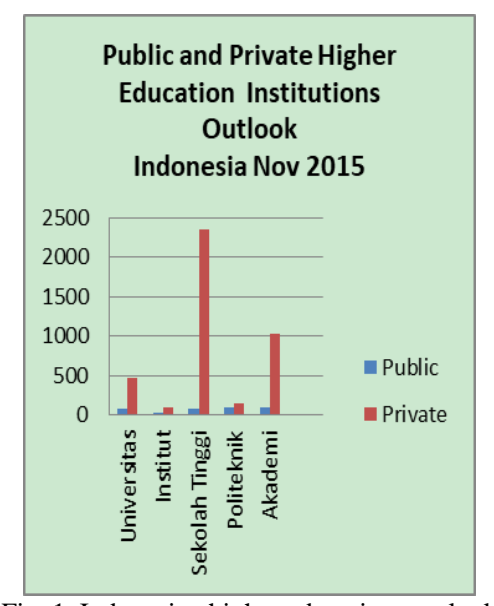

Fig. 1. Indonesian higher educations outlook.

The most staggering differences between public and private university is related to the availability of subsidy from the government. Public is defined as institution that receives financial supports from the government while private is defined as solely depend on their own source income generating activities. However it is not to be mistaken that private university in Indonesia is not neglected from the national calculation. The ministry of RISTEK DIKTI since 2010 has provided grants in accordance to the achievement of its aim to create a World Class University. Albeit limited, private university is eligible to access the funding of government under this framework of internationalization aid.

The strategy at play at the institutional level and its correlation with the overarching framework and global trend on internationalization is argued depend heavily on the unique character of each university. A study case on Parahyangan Catholic University (Unpar) will be presented to analyze the position of private university in delivering its internationalization strategy especially on the yearly period of 2015-2016.

\section{PRIVATE UnIVERSITY: UNPAR CASE}

The university was established in the year of 1955, 10 years after Indonesia's independent day. During that time Indonesia was busy with the national-building of the early republic. Public universities were limited, thus provided an impetus for the establishment of private university to nurture the development of the young nation. Most private universities in the early of independence time were spearheaded by religious supports in which Unpar is one of an example. While at the later time private universities emerged as a response to the increasing demand on education.

Essentially as a private university, the search of national fee paying students remains as Unpar main source of income. Its internationalization strategy is funded by the centralized budget of the University. With the mushrooming of private university nowdays, the competition is increasing. Furthermore, the decrease of national government and foreign education funding aid has put more strain in the financial management burden Unpar has to face. At the same time, internationalization activity is inherently costly, especially the cost of international trips one should take as part of university commitments to engage its foreign partners. A delegate consists of more than two person is rarely approved and deemed inefficient for university budget. Internationalization is often received less prioritization in comparison to the need of ensuring delivery of teaching activities nationally. How does Unpar undertake its wishes to engage internationally and what are the lesson can be learned from its status will be presented by looking at the internationalization strategy adopted.

In comparison to the global trend of internationalization strategy, Unpar has adopted a similar strategy to that of typical to the university in Asia Pacific. Unpar has been focusing on strategies to increase inbound students, followed 
by joint research and lastly encourage for the mobility of outbound student. This priority is highly determined by the available infrastructure that is planted by the university in term of internal regulations, financing mechanism and yielding result in number of students and joint research the university has received and sent.

However an additional different pattern can be concluded, in which Unpar incorporates the strategy of internationalization at home to each of its main strategies. The delivery of inbound-outbound students and joint research strategies cannot be separated from the internationalization at home strategy as this strategy proves to be efficient amidst the financial constraint.

To further boost its internationalization strategy, Unpar has also adopted an approach of nurturing and participating actively in small-middle and inclusive consortiums. These selected consortiums are chosen mainly based on its manageable size and benefits they could bring. Selecting an appropriate consortium can exemplify the efforts while keeping the budget under control. Membership fee will indeed arise from the participation on selected consortium. However, a multilateral meeting of several universities has proved to be more efficient in comparison to bilateral framework that requires more preparation and funding. The biggest challenge of selecting the right consortium depends on relating goals. In case for Unpar it is highly important to be involved in a consortium of the like-minded universities, with relatively same level of development and similar targets. Often, one consortium is not able to provide all interests; especially on working themes or regions coverage. It is thus wisely to be committed to several consortiums at once. Yet, one must avoid over-involvement in overlapping consortiums as it will render the effectiveness of its facilitating function.

TABLE III: COMPARATIVE INTERNASIONALIZATION STRATEGY

\begin{tabular}{|l|l|l|l|}
\hline \multicolumn{1}{|c|}{ Level } & $1^{\text {st }}$ & $2^{\text {nd }}$ & $3^{\text {rd }}$ \\
\hline Global & Outbound & Inbound & Research \\
\hline $\begin{array}{l}\text { Asia } \\
\text { Pacific }\end{array}$ & Inbound & Research & Outbound \\
\hline UNPAR & $\begin{array}{l}\text { Inbound } \\
\text { (internationa } \\
\text { lization at } \\
\text { home) }\end{array}$ & $\begin{array}{l}\text { Research } \\
\text { (internatio } \\
\text { nalization } \\
\text { at home) }\end{array}$ & $\begin{array}{l}\text { Outbound } \\
\text { (internationalizat } \\
\text { ion at home) }\end{array}$ \\
\hline
\end{tabular}

\section{A. Inbound Students}

Inbound students mobility comes as the top priority of Unpar internationalization strategy. The activities of receiving inbound student exchange have been applied even before the International Office of the University is established. Unpar received its first inbound student exchange in 2009 while the office has only come into being in the year of 2011. The inbound student mobility scheme is implemented on two biggest strands; semester exchange students and short semester student mobility.

Generally, the limited available funding forces universities to formulate alternatives ways to create its source of income [8]. Several universities have adopted the strategy of education's commercialization as a way to raise income. This commercialization strategy is well understood as a mechanism to attract foreign students on the search for fee-paying international students [9]. However this phenomenon is not applicable in Unpar. The university has been relying on national fee-paying students as the only source of income. The idea of international recruitment for fee paying students is rudimentary at best.

On financial aspect, inbound student exchange is eligible for visa cost and student support cost exemptions; ranging from subsidy on living cost, accommodation, cultural exposure and services of student buddies. Even the paying students is only entitled for a minimum financial obligation as mandated by the Rector. The university never debited the 'internationl revenue' into the budget calculation The hosting of foreign students is deducted from the operational budget of the office as it is clearly see as part of Unpar's internationalization strategy.

Inbound students thus, are understood not as income generator but as a tool of socialization of international elements for Unpar domestic constituents, both for staff and students. It is benefiting in its ability to encourage for cross-borders activities and also to encourage for exchange of technology/knowledge that will strengthen the teaching and research quality. This approach is widely known as internationalization at home. By bringing the international element to home, its posing itself as a suitable alternative internationalization strategy with less financial liability and at the same time providing wider international exposure.

In support to the approach, inbound student mobility in Unpar engages students and staffs in its activities through various programs such as workshops and study supervisors for staffs as well as students' buddies services providing opportunity for Unpar students to socialize with international students.

\section{B. Research}

Unpar research can be categorized into two levels: institutionally and individually. Unpar's institutional international research is done through the cooperation of GEM consortium (Global Entrepreneurship Monitoring) in which Unpar serves as the only representative of Indonesia. Individual researches profile within Unpar are more varied in its origins. Most of the joint researches are championed by doctoral degree holders with the help of master degree holders and students.

Internationalization at home is well adapted by research activities in its international visiting scholar policy. During their time in Unpar, international research also engages in teaching hours in classes or chairing workshop/seminar for the staffs. This capacity building events help on sharpening skills and knowledge transfer for staffs and students.

Additionally, owning a consortium that aims to encourage for joint research is essential to attain the international research goals. Some consortiums provide benefits on early funding support for joint research. Even the fund is not available the consortium itself facilitates a bank data of experts that could be utilize to engage matching partners in applying for research grants. As it is widely accepted that the cross-boundaries research is a trend preferred by donors, an international team certainly will have higher chance of success in attaining the international grants.

\section{Outbound}


Outbound students received less attention in the internationalization strategy of Unpar. On the course of five years, 2011 until 2016, in total UNPAR has sent only a total of 12 students for a semester based program. The number is significantly low in comparison that each semester Unpar receives up to 20 inbound students for a semester exchange program. Additionally, when we incorporate the number of short semester of inbound student mobility this number exacerbate the existing imbalance with approximate ratio of outbound to inbound, 1:10 yearly. In the year of 2016 only, the university receives up to 120 foreign students for a nonsemester program students and send 9 students in total for outbound programs.

University subsidy for outbound students, although increasing from 2015 financial budget year, only accounted up to $10 \%$ of the total budget of the International Office. Each year the International Office allocating budget for program to support students outbound mobility. Yet subsidy is given only to students' involvement on internationalization activity that is pre-approved by the university.

As the way to manage the fund efficiently, Unpar has decided to work within a consortium. This consortium is particularly relevant especially for student mobility scheme on fee waiver, scholarship/grant as well as possible future joint educational degree for students from respective universities. Focusing and committing to be involved in the consortium activities through a sustained manner will be resulting in positive cooperation for several reasons : the socialization process through a period of time within universities will create a sense of trust that will open up for a more possible cooperation. Partners are keen to be involved in several activities together. Positive deals can be negotiated with relative ease due to the established spirit of cooperation. It is thus imperative to support each member of the consortium in their internationalization activities as this treatment also ensures a reciprocal response from other partners.

\section{CONCLUSION}

Internationalization strategy adopted by Unpar is mirroring the Asia Pacific pattern in its reliance on accepting inbound students, followed by research and outbound students. Despite its status as private university and the inherent financial challenges its harbor in delivering its internationalization strategy, Unpar has adopted two important key concepts as the alternatives design to the internationalization strategy that deem efficient to attain the goal of internationalizations.

First, is the use of internationalization at home approach to promote internationalization strategy with an affordable budget and a wider exposure of international experiences both for students and staffs. Second, is the use of consortium as a core framework in which preferred cooperation can be take place. Commitment on long lasting cooperation and the development of trust with partners become the main points. This exempts university from unnecessary cost of looking for new partners through bilateral university to university (U-U) engagements. Multilateral setting is proved to be more efficient from the point of human resource and funding allocation. Being selective in engaging in international consortium becomes a highly important indicator of a successful internationalization strategy of private university in Indonesia.

\section{REFERENCES}

[1] Ministry of Research, Technology and Higher Education of Indonesia (RISTEK DIKTI), Forlap Dikti, 2015.

[2] J. Knight and H. Wit, Quality and Internationalization in Higher Education, OECD, 1999

[3] L. Rumbley, P. Altbach, and L. Reisberg, "Internationalization within the higher education context," The SAGE Handbook of International Higher Education, House, 2011, pp. 3-27.

[4] B. M. Kehm, "Research on internationalization in higher education," Journal of Studies in International Education, vol. 11, no. 3/4, 2007, pp. 260-273.

[5] J. Taylor, "Toward a strategy for internasionalisation: Lesson and practice from four universities," Journal of Studies in International Education, vol. 8, no. 2, 2004, pp. 149-171.

[6] G. Harman, "Internationalization of Australian higher education: A critical review of literature research," Internationalizing Higher Education, Springer, 2005, pp. 119-140.

[7] E. Polak and Hudson, "Internationalization of higher education: Global trends," Regional Perspectives: IAU 3rd Global Survey Report, 2010.

[8] U. Teichler, "Between over-diversification and over-homogenization Five decades of search for a creative fabric of higher education,' University Rangkings, Diversity, and the New Landscape of Higher Education, Rotterdam : Sense Publisher, 2009, 155-181.

[9] S. Guri-Rosenblit, "Internationalization of higher education: Navigating between contrasting trends," The European Higher Education Area, Springer, 2015, pp. 13-26.

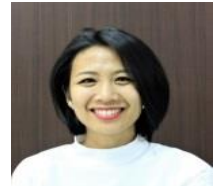

Ratih Indraswari received her BA in internationa relations from Parahyangan Catholic University, Indonesia and her MA in International Relations and International Organization from University of Groningen, the Netherlands. She is currently a lecture in International Relations Department and also the Head Division of International Cooperation, International Office of Parahyangan Catholic University, Bandung, Indonesia. 